\title{
The Extradition, between Iran Rights and International Rights, According to Palermo Convention
}

\author{
Mohammadreza Moradi Poshtdarbandi ${ }^{1}$ \\ ${ }^{1}$ Department of Rights Group of Azad University of North Tehran, Iran \\ Correspondence: Mohammadreza Moradi Poshtdarbandi, Department of Rights Group of Azad University of \\ North Tehran, Iran. E-mail: m.moradi.pd@gmail.com
}

Received: September 14, 2016

doi:10.5539/ass.v12n12p101
Accepted: October 8, $2016 \quad$ Online Published: October 29, 2016

URL: http://dx.doi.org/10.5539/ass.v12n12p101

\begin{abstract}
Extradition is a process which requires international judicial cooperation and its successful implementation will be the guarantor of justice and prevent impunity and escape the Probable criminals and suspects to countries far away from the crime scene. In the last two centuries globally in many countries have enacted expanded domestic law in the area of extradition to many extradition treaties and international conventions in this field has joined. Palermo Convention, including the most recent documents that contain comprehensive provisions on extradition and numerous countries has come to join in. In Iran in 1960 Legislator comprehensive and modern law in the area of extradition imposed And many international laws in this area has been invoked and respected. So, we gathered to view the article Ferraro circuit analysis on the world of law and the Palermo Convention and international law in the field of extradition elaborated on. The present article deals with these issues on two separate levels.
\end{abstract}

Keywords: extradition, the regulation of extradition, international law, Palermo Convention

\section{Introduction}

Judicial Justice Discourse requires that the criminals and violators of the laws be convicted as soon as possible through the criminal proceedings and their criminal judgment will be executed immediately. Prevention from not sentencing the criminals and escape of the criminals from legal punishments will guarantee survival and continuity of the criminal law system and value of the social norms from the viewpoint of the social administrators. Therefore, since the old years, as a person escaped from the place where the crime has been committed, the states would start cooperating and try to cause to return and transfer them to the country which is competent for dealing with the crimes committed by them. As Shambayati H. believed "In fact, extradition of the criminals is a process which indicates international cooperation of the countries to between execute the judicial justice rules. Extradition of criminals is one of the main discussions of the international law and criminal law which has had direct relationship with broad scope of the international rights, duties and powers of the states in order to struggle with the criminals. Therefore, this institution and its successful execution require cooperation of the countries and these countries shall make necessary cooperation in extradition of the criminals without political excuses".

\subsection{Statement of Problem}

Some issues such as protection of national power and sovereignty caused different countries to predict restrictions and rules in their laws relating to extradition and to design an instruction for paying attention to request of other countries for restitution. Therefore, these different conditions shall be considered in confrontation with today's international law discourse in attitude toward category of extradition. On this basis, clarification of domain and conditions for objectifying process of extradition of criminals in law of Iran and international regulations of Palermo Commission constitutes the main issue of this research and we will answer such questions based on it.

\subsection{Definitions and History}

\subsubsection{Definition and Meaning of Extradition of Criminals}

As Goldouzian (2012) defined "Extradition is the process through which the accused or criminal is extradited from the country to which he has escaped after committing crime and before conviction and punishments. The 
state which requests for extradition is called requesting state", and the state in which the accused resides and is requested for extradition is the called the extraditing state. In case there is special contract for extradition of criminals between the requesting state and requested state, it is compulsory to accept the extradition for the crimes predicted in the treaty and based on other conditions. Mirmohammad Sadeghi (2004) stated "But if there is no special contract between the requesting state and it is optional to accept or reject the request for the crimes beyond the treaty, it will be subject to tendency and will of the country which is requested to extradite or execute the criminal sentence. In latter case, extradition of criminal or execution of sentence will be subject to the presence of mutual relations". In other words, Sheikhi (2011) declared in legal sense, it means a set of actions which is performed for returning criminal from place of residence to the place where the offence has been committed. "Extradition causes certain execution of the punishment for the offender. Without rule, tradition and conditions of extradition, there will be a gap in execution of punishments because some countries find them unbound to some crimes which are committed in another country and as a result, the guilty foreigners will be safe against punishment due to residence in such countries. On the other hand, extradition of criminals causes the escaped criminal to be judged in court of the country where the crime has been committed and is more competent than any other authority while if it is stipulated that the accused be convicted in place of residence. The courts of another country will not be able to detect the fact and identity of the offender".

Undoubtedly, Ardebili (2006) believed "interest of the requesting state requires access to the offender who has violated justice of that country. Interest of the country which harbors the offender is that it will be freed of the person who may commit crime in that country. Considering the above cases, one of the goals of punishments is to inhibit and prevent the offender from escaping from punishment and judicial justice requires that the accused escapee in other countries not feel comfortable and safe and in case there is no international cooperation and the criminals can live in another country freely after committing crime and are not prosecuted, the justice will lead to chaos. Therefore, the issue of extradition is raised by feeling such necessity". Each of the countries enacts some regulations and conditions relating to extradition of the criminals and jurisdiction of the crimes committed by the criminals who are found in their land and accept principle of the criminals by observing principles and rules and principle of national sovereignty. Therefore, extradition of the criminals will result from judicial actions and international cooperation to prevent crime.

\subsubsection{Historical Records and Mental Basis of Extradition of Criminals in International Law}

As Ziayee Bigdeli (2002) said "In the past, Extradition of criminals is due to political and military crimes and when one of the opponents and rulers escaped from their country to another country for some reasons, their country intended to extradite the escapee but surrendering of the escapee depends on tendency and will of the extraditing state. Extradition more included political and military crimes". According to the historical precedent, extradition took global and international shape in Europe since century 18 later on by developing the mass media. The first country which prepared law about extradition is Belgium which started this action in 1833 .

Goldouzian (2012) stated "The first contract which Iran has concluded regarding extradition is the contract which it has concluded with Afghanistan in 1928 has been invalidated due to expiry of term of the contract. Iran concluded a contract with Turkey in 1937 and then in 1959 and 1966, concluded extradition contracts with Pakistan and France. Finally in 1960, law for extradition of criminals was enacted in Iran as the first comprehensive law in this regard".

Generally, basis of extradition is mostly on local and national laws or international contracts and treaties or the customary rules of the international law. As a customary rule, As Nourbaha (1997) stated, "the states shall respect for national sovereignty of each other and make cooperation with each other to gain access to violators of the laws and norm breakers. This rule has turned into mental method of extradition process and it has been reflected in local laws of many countries. The dominant explanatory basis which is followed in the said rules and contracts for necessity of extradition of criminals is to help administration of justice and prevention of injustice. In fact, there is belief that regulations for extradition of criminals help administer justice because it should be prosecuted and punished assuming that the accused or convict takes refuge in another country. Therefore, impunity will be prevented". Since the states require establishment of order for establishment of sovereignty, struggling with crime inside borders of a country is regarded as one of the most important subjects and governments codify laws and regulations for achieving these goals and imposing punishments on criminals and according to principle of territoriality of crime. According to Mohseni (1996) "Although all inhibiting arrangements against criminals are applied for preventing from escaping to other countries and their criminal prosecution, the criminals escape from the country where they have committed crime in different ways after committing crime and before detecting it. The governing body shall prosecute these criminals according to principle of necessity of punishment of criminal based on governmental laws and systems and to protect society 
against crime and criminal phenomena.

In this stage of criminal prosecution, application of laws and regulations for extradition of criminals and observance of the related formalities will be required to execute the binding punishments for them after extraditing the criminals by virtue of the judgments issued by the judicial authorities. Performance of this important fact will be subject to necessary means fort prosecution and arrest of the criminals in another country and finally extradition of them to soil of the requesting country. On this basis, the first starting point of organizational establishment which can prevent the escapees from taking refuge in all parts of the world emerged in global thoughts and Interpol Commission emerged in 1923. This Commission changed its name into Interpol Organization. Central administrations of Interpol in the member states were also equipped with the recent police, prosecution and care technology and to carefully identify the criminal and criminal victim and control water, air and land borders of the countries under careful supervision of the police officers to prevent escape of the criminals to foreign countries. However, the professional criminals successfully exit from the country by achieving desirable conditions and utilizing their opportunities and hiding their identity. Therefore, it is necessary and undeniable to reinforce strategies of the legal systems in this regard and this clarifies necessity of reinforcing mental fundamentals and logic of the propositions of the extradition process".

\subsubsection{Research Questions}

- What is the attitude of the legal system of Iran to the extradition body?

- What are the rules proposed by the Palermo Commission regarding extradition of the criminals?

\subsubsection{Hypothesis}

The general rules of extradition of the criminals in law of Iran conform to the prevailing regulations of the extradition of criminals in Palermo Commission.

\subsubsection{Research Method and Data Collection}

This research studies extradition of criminals in law of Iran and international law in analytical and descriptive manner and also its data has been collected through review of legal literature.

\section{Review of Literature}

\subsection{Study of the Rules and Conditions of Extradition in Law of Iran}

In the present condition, law of extradition of the criminals enacted in 1960 and the contracts concluded between Iran and other countries constitute legal documents of the extradition body in criminal law system of Iran. According to Article 1 of the criminals extradition law, in case extradition contract is concluded between Iran and foreign states, extradition will be done according to the conditions mentioned in the contract and in case the contract is not concluded or if it is concluded and it doesn't include all necessary points, extradition will be done according to regulations of this law on the condition of mutual transaction. Anyway, the extradition body has different conditions and rules based on type of crime, persons who shall be extradited and the state which requests extradition. Therefore, we analyze and study them separately and in detail.

\subsection{Conditions for Extradition Based on Type of Crime}

In order to perform extradition process, the committed crime has special descriptions and conditions. In fact, any crime shall not be necessarily extradited but some of the crimes have been excluded from the extradition rules for different reasons. Different conditions which relate to possibility of extradition based on type of crime and its related issues include:

\subsubsection{The Committed Crime Is a Dangerous Act Which Deserves Severe Punishment}

In fact, request for extradition is not accepted in less important crimes. Brayan (2009) stated "In the past, important crimes were reckoned and defined through the regional or international treaties but it was not possible to continue this trend due to expansion and increase of crimes and was forgotten gradually. Today, instead of these crimes, general rules have emerged for recognition of the instances of the important crimes. For example, it is said that the crimes which have custodial sentence for more than 2 years, the offender will be extradited. Law for extradition of Iranian criminals have followed this trend and they accept extradition regarding the crimes for which the legal punishments last more than 1 year of imprisonment or the criminals have more than 2 month conviction. Therefore, if a crime has punishment below 1 year or below 2 months of imprisonment, the offender will not be extradited".

In this regard, Article 4 of the law for extradition of criminals has stipulated that request for acceptance or rejection of the extradition of criminals is also possible by observing regulations only in the following crimes: 
1- Regarding any action which requires criminal punishment according to the requesting laws.

2- Regarding any action which requires misdemeanor punishment provided that the maximum punishment stipulated in the law is not less than 1 year. For those who have been sentenced, extradition will be possible when term of conviction is more than 2 months of imprisonment. Article 6 also stipulates that in case the requested person commits some crimes, if the maximum punishment which has been stipulated for the committed crimes is not less than 1 year, extradition will be possible though the punishments which have been stipulated for the next crime by virtue of law is less than 1 year of imprisonment and the conviction which is less than 2 months of imprisonment.

\subsubsection{Rule of Double Criminality Shall Be Established for the Committed Crime}

In this respect, it is said that the criminal act shall be regarded as crime in both countries. Therefore, if the committed crime is not crime in domain of the country where the criminal has taken refuge, the extradition will be cancelled. In this regard, Article 4 of law of extradition stipulates that: in all cases said in this article, extradition will be accepted by Iranian government when the committed act requires criminal or misdemeanor punishments.

\subsubsection{Rule of Specificity Shall Be Established for the Committed Crime}

It means that the extradited person shall be convicted for the accusation due to which he has been extradited. Therefore, it is impossible to change type and nature of claim and criminal title attributed to the persons to be extradited.

\subsubsection{Committed Crime Shall Not Include Criminal and Military Crimes}

As a general and customary rule in the field of international law, it is not possible to extradite the criminal for political and military crimes. For this reason, in law regarding extradition of the Iranian criminals, the legislator has cancelled acceptance of the request for extradition in these crimes. It has been stipulated in Article 8 of this law:

In the following cases, extradition will not be accepted.

1- In case the committed crime is one of the political crimes or it is evident from circumstances of the case that extradition has been done for political purposes.

2- In paragraph 4 of the said article, it has been stipulated that in case the committed crime is one of the military crimes, extradition will not be accepted.

3- For the local disputes and wars, extradition will not be accepted unless the actions which have been committed are cruel or contrary to regulations of war. In this case, extradition will be acceptable after end of the local wars.

\section{Purpose of the Study}

\subsection{Investigation of Terms of Extradition}

\subsubsection{Conditions of Extradition Based on the State Which Requests Extradition}

According to a general rule in the international law, as Brayan (2009) declare, the states have predicted special conditions in their local laws for acceptance of request for extradition which are satisfied based on permission and possibility of acceptance of request for extradition. In this regard, the Iranian legislator has referred to different conditions for acceptance of request for extradition in the law for extradition of criminals. The most important conditions are as follows:

1- By virtue of paragraph 1 of article 3 of the law for extradition of criminals, the crime shall be committed by nationals of that state or nationals of another state in domain of the requesting state. In fact, the principle of the territorial jurisdiction shall be applied by the requesting state.

2- By virtue of paragraph 2 of article 3 of the said law, in case the crime has been committed by the nationals of that state out of the domain of the requesting state. This alternative of the Iran extradition law refers to possibility of applying the positive personal jurisdiction through which the states acquire the jurisdiction over the crimes committed by the nationals out of their territorial domain.

3- Another condition, according to paragraph 3 of Article 3, is that the crime committed out of the domain of the requesting state and by a person not among nationals of that state provided that the committed crime damages public interests of the requesting state. This condition refers to the principle of real jurisdiction in the international criminal law through which a crime is committed against the high interests of a country out of the 
territory of that country, the said country will; have jurisdiction over the committed crime by applying the principle of jurisdiction. In Article 12 of the law for extradition of criminals, it has been stipulated that in case some states request for rejection due to different crimes, the requested person will be surrendered to the state which has right of priority. Right of priority will be determined considering Article 10 based on importance of crime and place where it has been committed and date of rejection and the obligation of the requesting state to reject the criminal.

\subsubsection{Conditions for Extradition Based on the Extradited Persons}

According to the general rule, as Ahmadi (2005) said, the states will agree on request for extradition when firstly the criminal is not their national and secondly the committed crime is not included in their jurisdiction by any means. In fact, the first condition of the principle for prevention of extradition of the local nationals is applied and based on this condition; the states will not return the criminal as their national to another country to hear the committed crime. This rule that has been confirmed and emphasized in Articles 3 and 9 of the law for extradition of criminals has been also observed in all contracts of extradition concluded by Iranian government. In fact, the local nationals accused of crime will be subject to criminal regulations of Iran and they will not be extradited when they have committed crime in Iran or have committed crime out of Iran since the rule or principle for prevention of dual conviction will prevent extradition of the accused or convicts as the local nationals to other countries. It is worth noting that, in article 6 of the European Treaty on Extradition of criminals, principle for prevention of extradition of the local nationals has been accepted as a relative and optional rule. Therefore, based on this treaty, according to Robert (2010), "the states are free to extradite their nationals to the place where the crime has been committed if they deem it proper". On the other hand, in case, the person who has committed crime shall be prosecuted and punished in Iran, request for extradition will not be accepted. Based on Article 8 of law for extradition of criminals, As Ahmadi (2005) stated, "if the criminal who has committed crime in Iran or committed crime against high interests of Iran out of Iran cannot be extradited and Iranian government will be able to hear the crime based on principles such as positive jurisdiction and real jurisdiction". It is also worth noting that with reliance on Article 7 of Law for Extradition of Criminals, in case the requested person has been prosecuted or convicted for the crime which he has committed, his extradition will not be extradited.

This will be possible if the committed act is barred by limitation or leads to issuance of judgment of acquittal or order of non suit and nolle prosequi for legal reasons. In addition, starting to commit crime is regarded as the crime itself according to regulations of extradition. According to Article 13 of the law for extradition of criminals, if the Iranian government is the addressee of the extradition body, request for extradition will be sent through Ministry of Foreign Affairs to Ministry of Justice. In case Ministry of Justice recognizes extradition according to legal regulations of this law, it will refer the case to the prosecutor's office of the local county where the requested person resides or if the requested person has no known residence place, it will be referred to prosecutor's office of the county of Tehran to take action for arresting him.

\section{Discussion}

\subsection{Study of the Rules and Regulations of the Extradition in Palermo Commission}

\subsubsection{Rules and Regulations of the Extradition in Palermo Commission}

Brayan (2009) defined "Palermo Commission enacted in October 2000 is one of the most important documents in the international law for struggling with organized and transnational crimes and different forms of corruption which opened new door to the criminal law in the field of these crimes. In this document, some issues such as extradition of criminals have been dealt with in addition to substantive issues and detailed regulations have been elaborated in this field. In this document, there are spirit and logic of international treaty in which some rules such as international collaboration, obligation to perform international commitments etc. shall be followed. In this regard, treaties for extradition and documents and treaties which contain materials about extradition are of the most important legal basis of extradition in the international law. These treaties bind the parties to treaty to extradite the persons who have committed misdemeanor and crime and are prosecuted to their country in definite cases. Therefore, if one of the states to the treaty refuses to extradite the criminal who shall be extradited without any reason, it will be deemed to behave contrary to the treaty".

According to Sedigh (2008) "The treaties in international law are regarded as international codified law and are regarded as the fastest and the most reliable sources of international law. Treaties may be concluded between two or more states and the subject is confirmed according to the rules and principles of the international law and sometimes, it creates a new rule in the field of international law. Some of the international treaties which have been directly concluded by the states in the field of extradition of the criminals or are related to the subject are regarded as fundamentals of extradition like the treaties by virtue of which direct surrendering of the criminals or 
request for extradition has been predicted by the judicial authorities of the countries. One of the specifications of the treaties for extradition of criminals after being approved by the states is its compulsory nature. It means that the states are free to conclude or not conclude the treaties. However, conclusion of interstate treaties regarding extradition of criminals adds compulsory characteristic to it for the crimes which have been stipulated in the treaty and make extradition compulsory in cases which have been stipulated. Anyway, Palermo Commission is one of the instances of the treaties", which contain comprehensive and detailed regulations relating to category of the extradition of criminals. Article 16 of this commission relates to extradition of criminals. Palermo Commission in this article has independently dealt with extradition of criminals. But the point here is that most insertions of this article reflect the international customary rules. In fact, this factor is an effective factor in more encouragement of states to join this convention because the customary and international rules which were executed among the states for the said subject since the past have emerged as Palermo Commission. In fact, consultative or compulsory nature of most articles and paragraphs of this convention encourage the states to join it. In Article 16 of Palermo Commission, different rules and regulations have been predicted for extradition of criminals, which are consistent with general spirit of rues of this international document and they can be summarized in the following paragraphs:

I. Provisions of regulations will be applied for extradition for the crimes under this convention or in case an organized criminal group interferes in committing criminal act inserted in paragraphs A and B of Article 3 i.e. severe crimes and money laundering, corruption and prevention of good administration of justice and committing crime against judicial justice and the person whose extradition is requested is present in domain of the requested member state provided that the crime for which extradition has been requested is punishable.

II. If request for extradition includes some severe independent crimes some of which are not subject to this article, the requested member state can apply regulations of this article for those crimes.

III. Each of the crimes for which regulations of this article is applicable will be included in the extraditable crimes in each treaty of extradition among the member states.

IV. In case a member state makes extradition dependent on a treaty and if it requests another member state with which it has not concluded treaty for extradition of criminals to extradite the criminal, it can regard this convention as a legal basis for extradition for each of the crimes under this article.

V. The member states which make extradition of criminals dependent on availability of treaty:

a) When the document for approval, acceptance, confirmation or addition to the present convention is given, the Secretary General of United Nations is informed if this convention is considered for extradition or not.

b) If they don't regard the present convention as a legal basis of cooperation in extradition, they will conclude treaties regarding extradition with other states of the present convention to execute this article.

VI. The member states who don't make extradition of criminals conditional on the availability of treaty will regard the crimes to which this article is applied as extraditable crimes among them.

VII. Extradition of the criminals can be regarded by observing the conditions predicted in the local laws of the requested member state or provisions of the treaties for extradition such as minimum punishment condition for extradition and the reasons with which the requested member state can prevent extradition of criminals.

VIII. The member states considering the local laws will try to accelerate formalities for extradition and simplify the evidence in substantiation of claims for each of the crimes to which this article is applicable.

IX. A member state will be permitted to extradite its nationals or surrender them in any other way based on its local law if the said person is requested for extradition to pass the issued sentence as a result of trial. In this case, the states will agree on this request conditionally.

$\mathrm{X}$. Any person who is prosecuted for each of the crimes under this article shall be conducted with fair trial in all stages and can enjoy all rights and guarantees predicted in the local law of the member state in which he has committed crime.

XI. None of the insertions of this convention shall be interpreted such that the requested state is obliged to extradite the criminal while the said state has justified reasons for no extradition or regard extradition as racial, gender, religious or nationality excuse or subject to tribal and political prejudices and thoughts.

XII. The member states cannot prevent execution of request for extradition for financial reasons due to costly process of extradition.

XIII. To provide enough opportunity for the requesting state to mention its views and give evidence and 
information for extradition, the requested state will consult with the requesting state at its discretion and before rejection of the request for extradition.

Robert (2010) stated "The above information shows that general rules for extradition of criminals in law of Iran are consistent with most regulations of the extradition of criminals in Palermo Commission. Some cases such as obligation of states to consult before rejection of request for extradition, attention to political, religious, ideological and racial motives which prevents from acceptance of request for extradition and also the regulations regarding necessity of observing rules of fair trial to execute process of extradition of criminals in this convention are among the rules to which the Iranians law for extradition of criminals has not expressly referred and against which it has not taken special position". Of course, it seems that these foundations emphasized by the Palermo Commission have been covered in other manuals and legal regulations in Iran and one may not mention their absolute termination in scope of the present legal system of Iran. Anyway, there are minimum cases in many regulations including the law for protection of citizenship rights and law for establishment of public and revolutionary courts in criminal cases and they imply attention of Iranian legislator to some issues such as fair trial and its parts and protection of legitimate rights of the accused and convicts in all processes of criminal trial. At the end, as explanatory introduction of the Palermo Commission refers, in case the treaty of extradition of criminals is not concluded among the states and in cases a state has not codified a law for extradition of criminals and the states extradite criminals to reject criminals from other societies who have taken refuge in their countries and also protect internal security considering the international custom and usage, the certain and binding condition in these extraditions is not the reciprocity of the states but the states extradite the refugees to their country. Trechel (2005) believed "Although the criminals or the accused who shall be extradited object to lack of treaty for extradition or failure to observe the regulations of the extradition or their committed crime doesn't lead to extradition, it should be noted that rules and conditions for extradition for protecting the accused and criminals are not enacted but they are enacted based on international needs and need of human societies and protection of mutual relations of the states". Therefore, according to Henry (2010) "the accused or criminal cannot object to legitimacy or non-legitimacy of the extradition and these states make decision about extradition of the criminals and accused who took refuge to their country considering international custom and usage because the international custom is a series of rules which have been concluded during centuries and different eras and is regarded as a fundamental documentary source in the international law. For example, international custom in courts of Nuremberg and Tokyo was one of the principles which the judges of these courts applied".

\section{Conclusion and References}

\subsection{Conclusion}

Extradition of criminals is a process which indicates international collaboration of countries to execute rules of judicial justice more carefully. Extradition of the criminals is one of the main issues of international law and criminal law which has direct relationship with broad scope of international rights, duties and powers of the states to struggle against criminals. Therefore, this body and its successful execution requires cooperation of states and these countries shall make necessary cooperation in extradition of criminals without any political and security excuse. The dominant explanatory basis in regional and international rules and contracts which is followed for extradition of criminals is to help administer justice and prevent injustice. In fact, there is belief that regulations for extradition of criminals help administer justice because given that the accused or convict takes refuges to another country, he shall be prosecuted or punished. Therefore, injustice will be prevented. General rules for extradition of criminals in law of Iran are consistent with most of the regulations for extradition of criminals in Palermo Commission. Only some cases such as obligation of states to consult before rejection of request for extradition, attention to political, religious, ideological and racial motives in Palermo Commission which prevent acceptance of request for extradition and also the regulations for observance of the fair trial rules to execute extradition of criminals in this convention are among the rules to which expressly referred and against which it has not taken special position.

\section{References}

Ahmadi, M. (2005). Transfer and Extradition. Journal of Law and Jurisprudence, 15, 123-144.

Ardebili, M. A. (2006). General Criminal Law. Tehran: Mizan Press.

Ashworth, A. (2005). Sentencing and Criminal Justice (4th ed.). Cambridge University Press.

Brayan, E. (2009). The transition of criminals (1st ed.). London: Open University Press.

Goldouzian, I. (2012). General Criminal Law (12th ed.). Tehran: Tehran University Press. 
Lavasani, M. (1969). International crime. Journal of Canon, 89, 181-198.

Mirmohammad Sadeghi, H. (2004). General Criminal Law. Tehran: Dadgostar Press.

Mohseni, M. (1996). General Criminal Law. Tehran: Ganje Danesh Press.

Nourbaha, R. (1997). Area of General Criminal Law. Tehran: Ganje Danesh Press.

Robert, M. H. (2010). Two problems in regard Transition of offenders. New York: Rootlain Publishing.

Sedigh, M. R. (2008). Transnational Organized Crimes (1st ed.). Ilam: Raman Press.

Shambayati, H. (2006). General Criminal Law. Tehran: Majd Press.

Sheikhi, A. M. (2011). Extradition. Online Journal of Legal Rights.

Trechel, S. (2005). Human Rights in Criminal Proceedings. Oxford: Oxford University Press.

Von Hirsch, A. (1985). Past and Future Crimes: Deservedness and Dangerousness in the Sentencing of Criminals. New Brunswick: NJ Rutgers University Press.

Ziayee Bigdeli. (2002). General International Rights. Tehran: Allameh University Press.

\section{Copyrights}

Copyright for this article is retained by the author(s), with first publication rights granted to the journal.

This is an open-access article distributed under the terms and conditions of the Creative Commons Attribution license (http://creativecommons.org/licenses/by/4.0/). 